University of New Hampshire

University of New Hampshire Scholars' Repository

Art and Art History Scholarship

Art and Art History

1992

\title{
Asleep in the grass of Arcady. Giulio Campagnola's dreamer
}

Patricia Emison

University of New Hampshire, Patricia.Emison@unh.edu

Follow this and additional works at: https://scholars.unh.edu/art_facpub

Part of the Ancient, Medieval, Renaissance and Baroque Art and Architecture Commons

\section{Recommended Citation}

"Asleep in the Grass of Arcady. Giulio Campagnola's Dreamer," Renaissance Quarterly, XLV, 1992, pp.

271-92.

This Article is brought to you for free and open access by the Art and Art History at University of New Hampshire Scholars' Repository. It has been accepted for inclusion in Art and Art History Scholarship by an authorized administrator of University of New Hampshire Scholars' Repository. For more information, please contact Scholarly.Communication@unh.edu. 


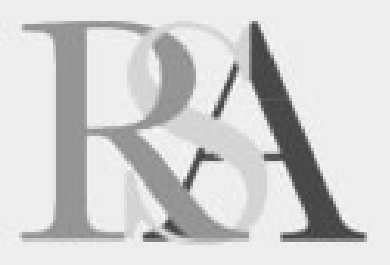

Asleep in the Grass of Arcady: Giulio Campagnola's Dreamer

Author(s): Patricia Emison

Reviewed work(s):

Source: Renaissance Quarterly, Vol. 45, No. 2 (Summer, 1992), pp. 271-292

Published by: The University of Chicago Press on behalf of the Renaissance Society of America

Stable URL: http://www.jstor.org/stable/2862749

Accessed: $21 / 02 / 2013$ 09:37

Your use of the JSTOR archive indicates your acceptance of the Terms \& Conditions of Use, available at

http://www.jstor.org/page/info/about/policies/terms.jsp

JSTOR is a not-for-profit service that helps scholars, researchers, and students discover, use, and build upon a wide range of content in a trusted digital archive. We use information technology and tools to increase productivity and facilitate new forms of scholarship. For more information about JSTOR, please contact support@jstor.org.

The University of Chicago Press and Renaissance Society of America are collaborating with JSTOR to digitize, preserve and extend access to Renaissance Quarterly. 


\title{
Asleep in the Grass of Arcady: Giulio Campagnola's Dreamer*
}

\author{
by Patricia Emison
}

$\mathrm{T}$ HE RAREST FIGURAL VIEW IS THAT involving a protagonist seen from behind, not directing a look outward toward the spectator. One such example is Giulio Campagnola's engraving of a solitary woman in a landscape, seen in a three-quarters rear view (fig. I). Radically stripped of iconographic attributes as it is, this print is less narrative, or even lyrical, in its presence than many pastoral compositions. Here there is no warm, atmospheric, and mellow world of wish-fulfillment as in the Dresden Venus. ${ }^{\text {I }}$ Giulio offered no paper Giorgione but rather a place in which lush vegetation clashes against sharp turrets, and no Cupid attends upon dormant, soft female flesh. Giulio distanced the image from predigested literary conventions. Yet the art historical inclination is to assimilate Giulio's work to Giorgione's, and furthermore to understand Giorgione's importance as consisting in his visualization of the hitherto literary world of pastoral. Ut pictor poësis can be too handy an axiom.

*A version of this paper was delivered at the Renaissance Society Annual Meetings, Cambridge, MA, April, I989. A longer lecture was delivered at Wellesley College in February, I990, as part of the series "Court and Culture in the Renaissance." My thanks for comments given on both occasions, for a reading by Peter Parshall scrupulous on multiple levels, and especially to David Feldman, who has helped throughout. My work on this subject extends back to my doctoral thesis at Columbia University, "Invention and the Italian Renaissance Print, Mantegna to Parmigianino" (1985), advised by David Rosand.

'Giorgione's Dresden Venus has been called by Georg Richter the first chef d'oeuvre of the High Renaissance in northern Italy, a perfect expression of the spirit of Humanism, and an example of specifically Greek classicism. Though the interpretative aspects of these pronouncements have been subject to revision (see below), the cardinal importance of the work is still maintained. Giorgione established the reclining female nude as a major artistic theme. Thereafter, Giorgione's example was modified in a variety of directions. Cf., for example, Girolamo da Treviso's Sleeping Venus in the Galleria Borghese from the early i 520 (Hope and Martineau, I73, no. 40.) and Cariani's Dahlem portrait(?) from approximately the same time of a woman luxuriating in the landscape with a pet lapdog (see Katalog, 89, no. I 85.). Both, significantly, have flaming landscape backgrounds. For an introduction to the subject of erotic imagery in the visual arts of the Renaissance, see Ginzburg, I25-35; Frantz, I 18-39; and, less specific to the Renaissance period, Freedberg, I $3-32$.

\section{[27I ]}




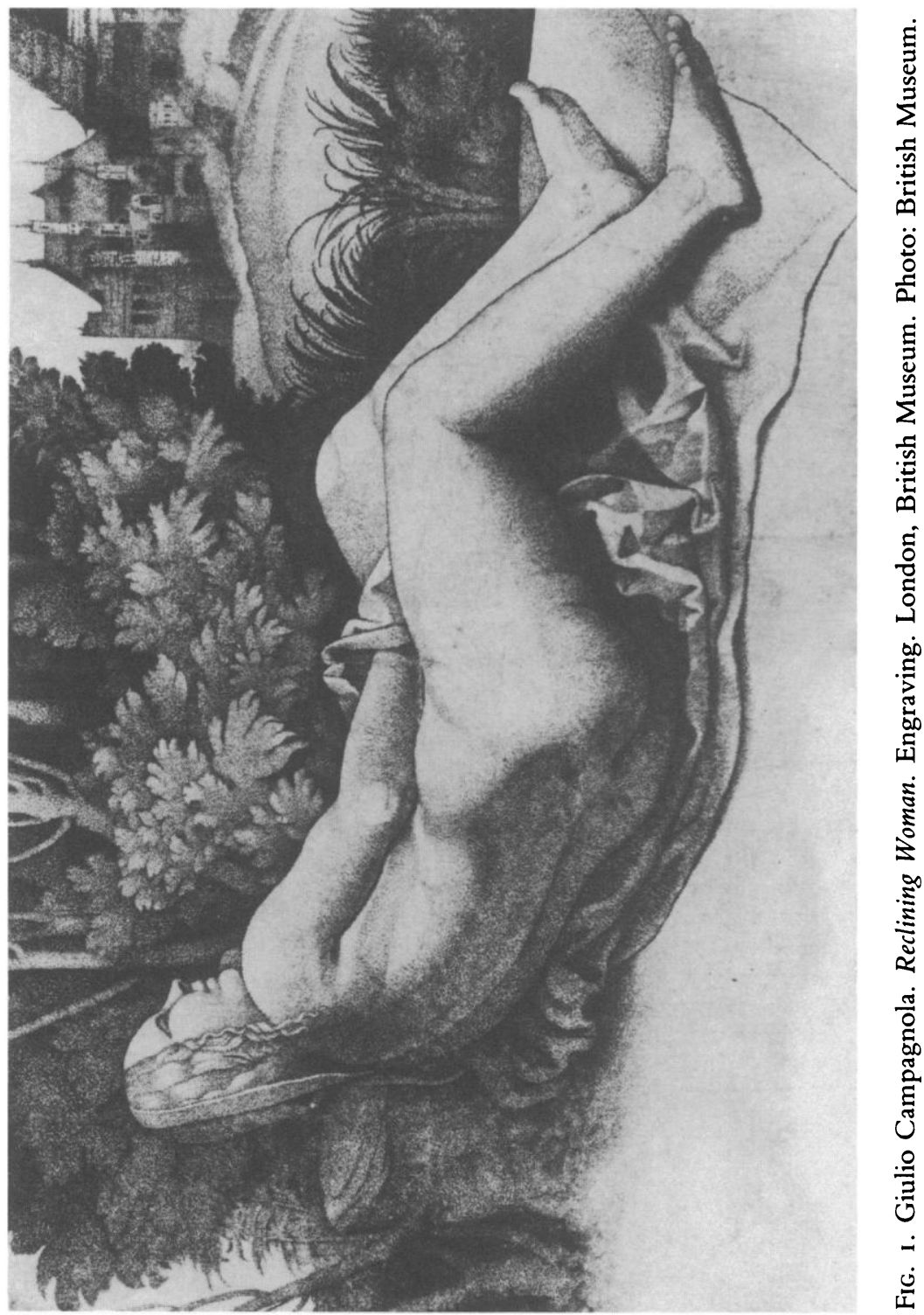




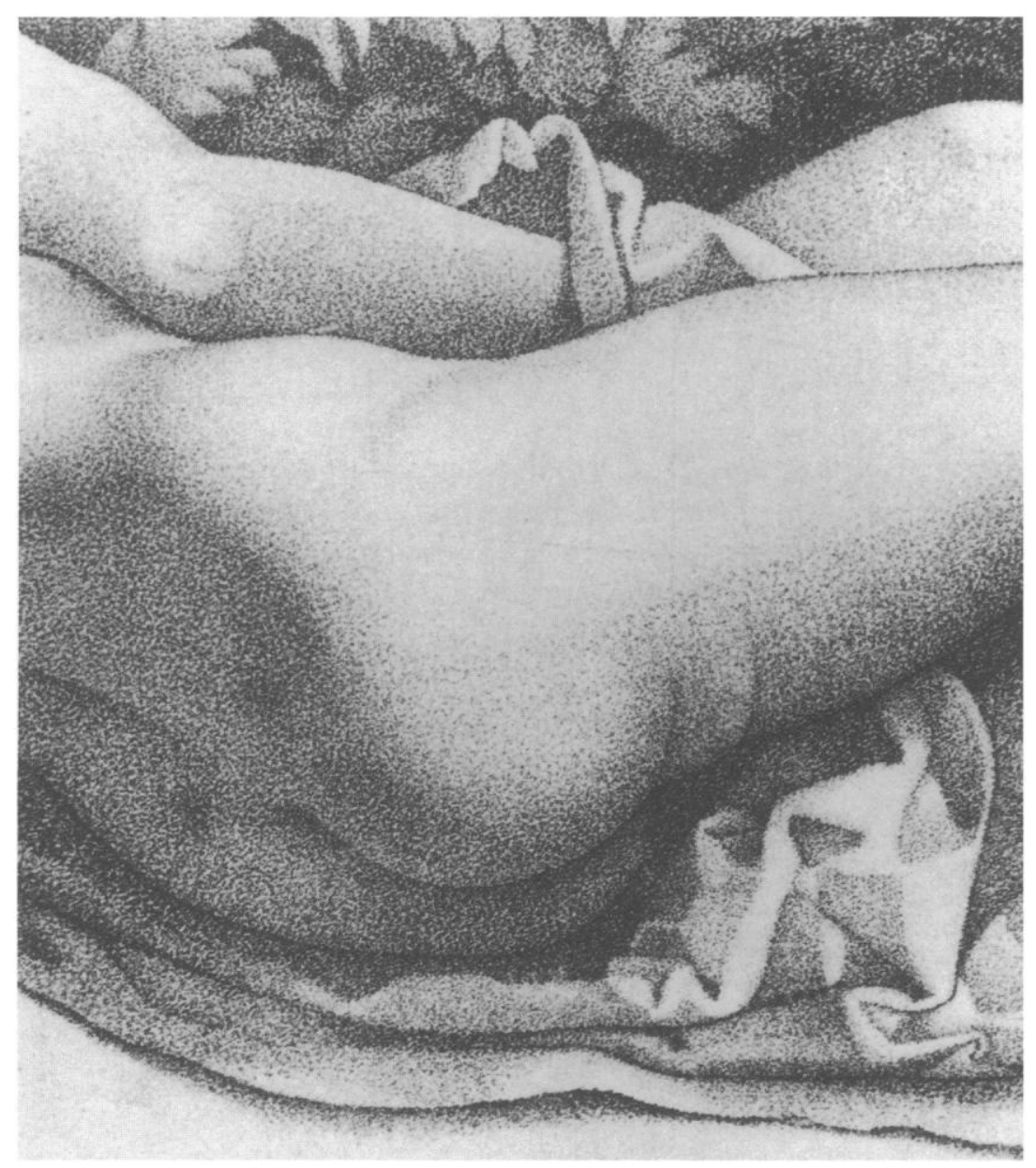

FIg. 2. Giulio Campagnola. RecliningWoman. Detail. The Cleveland Museum of Art. Gift of the Print Cub of Cleveland. Photo: Cleveland Museum of Art.

Though simple, even reductive, on the scores of iconographic attributes and focused action, technically this work achieves a zenith of complexity. It is virtually certain that this small engraving ( I $2 \times$ I $59 \mathrm{~mm}$.) had one of the most limited editions among Ren- 
aissance prints, if the term edition is even appropriate to a work that was done in so special a technique. Laborious stipple marks, like gnats on a summer evening, as A. H. Mayor once described them, ${ }^{2}$ give a tonal effect such as no one else approximated until the advent of aquatint (fig. 2). ${ }^{3}$ Even among Giulio's engravings, this is the only one utterly devoid of line. The Reclining Woman was copied once, crudely. ${ }^{4}$ Both this copy and Titian's direct borrowing from the engraving, in his late painting of a nymph who does address the viewer, ${ }^{5}$ assure us that the print was not utterly obscure, however limited the number of impressions. Giulio Campagnola was known to the leaders of Venetian culture, including Aldus Manutius and Pietro Bembo. His works, if not widely accessible, surely were known in interesting places and by men who already owned paintings and were not in the market for surrogates. In making this print, Giulio addressed a special public - sophisticated, critical, and not in a position to be flattered like the patron of a unique painting.

Marcantonio Michiel described a miniature owned by Pietro Bembo in terms that suggest a strong similarity to the present engraving. Michiel jotted down that he had seen: "una nuda tratta da Zorzi, stesa e volta" ("a nude drawn from Giorgione, reclining and turned"). ${ }^{6}$ This documentary reference and an engraving by Marcantonio Raimondi which uses an apparently related reclined female form (B. 359) have been the traditional beginning points for the consideration of Giulio's engraving. Though I shall return to this evidence later, first I intend to argue that Giulio's work is to be understood not as an illustration, however generic, of pastoral myths, but as the most succinct of treatises on the nature of women.

${ }^{2}$ Mayor, I92-96; also 735-38.

${ }^{3}$ Cf. the engravings of Marcello Fogolino, the Master PP, and Daniel Hopfer (B. VIII, I6, 90).

${ }^{4} \mathrm{Hind}, \mathrm{V}, 202$, nos. I 3 and I 3 a. He records eight impressions; that in Cleveland is signed in pen and ink in the lower left corner, seemingly by the artist. Hind calls the engraving Venus Reclining in a Landscape. Giulio, it should be noted, was not a professional engraver. His total oeuvre consists of about fifteen engravings. See more recently, Zucker, 473-76, .o08; and Russell, I32, I 38-39.

'On the painting in Vienna, see Goldner, 392-95. For a discussion of the painting's sinister version of pastoral imagery, see Cook, $44-45$, and, relating the type to the earth goddess as represented on Roman sarcophagi, Saxl, I: I7I-72.

6". Li dui quadretti di capretto inminiati furono di mano di Julio Compagnola; luno è vna nuda tratta da Zorzi, stesa e e volta, et l'altro una nuda che da acqua ad vno albero, tratta dal Diana, cun dui puttini che zappano" (Frimmel, 22). See also Pignatti, I66, and Eiche, 353-59. Nothing is known of the fate of these miniatures. 
The usual Arcadian earmarks - satyrs, shepherds, and so forthhave been omitted for good reason. Neither an outright recrimination against women nor, certainly, a homage to them, Giulio's image is a complex expression of attitudes toward women. Despite its seeming remoteness from daily life, the image is more about that than about Arcady.

Many images of women in the art of Giulio's time demand entreaty-be they the Dresden Venus or the Virgin Enthroned. There are also risqué, burlesque portrayals of nymphs stumbled upon by satyrs, such as the early engravings by Marcantonio Raimondi or the prints of the Master of I I I 5 . The latter reflects frivolous manuscript marginalia, such as that produced by the Paduan followers of Mantegna. The first appearance of a sleeping female nude, among the woodcuts of the Hypnerotomachia Poliphili ("figure vetuste, in geometria che poco costa"), owes something to both types. The reclining woman of the "Panton Tokadi" woodcut, though approached by a satyr and two cupid-sized satirelli (in the woodcut), is treated with awe by Polifilo (in the text). Her mixed status as nymph and Venus and her inauguratory role as sleeping pagan divinity was the subject of Millard Meiss' well-known essay some twenty-odd years ago, since corrected by Jaynie Anderson's discovery of antique prototypes, both literary and visual. 7 Her interpretation of the image as a tribute to a carnal definition of Venus emphasized the Cupid holding a bird and pointing an arrow at his groin, an item discretely painted out in modern times. Although Meiss acknowledged the eroticism of the image-calling the gesture of the Dresden Venus "a very bold adaptation [of the Venus Pudica pose] in which concealment yields to demonstration"- he maintained all the while that sleep was a removal or distancing of a figure that mellowed or made dreamy any erotic content. ${ }^{8}$ The context he tried to establish for the interpretation of the Dresden

${ }^{7}$ Meiss, 212-39; Anderson, 337-42.

${ }^{8}$ Only in a footnote did he acknowledge that the Venus Pudica gesture rightly belongs to a standing figure. Freedberg, I34, comments that the left hand "denotes not the act of love but the recollection of it" and says of the figure "she dreams his [Giorgione's] dream herself." For a recent re-evaluation of the eroticism of the Dresden Venus, see Goffen, 682-706. She finds this to be an image of "woman's sexuality, dangerous, to be sure, but given appropriate expression in marriage," and interprets the gesture as distinctly masturbatory, bearing with it connotations of fertility. Paul Kaplan gave a talk on the same subject at the I990 CAA annual meeting, entitled "The 'Dresden Venus' and Other Renaissance Images of Female Autoeroticism." 
Venus was none other than the iconographic type of the sleeping Christ Child in combination with the identity of Venice herself as La Serenessima.

To make dreamy and to make mellow can be very different things. Giulio's engraving falls distinctly outside the boundaries of idealizing images of sleep. Though her eyes are closed, there is no certainty that Giulio's figure is sleeping. We may well be voyeurs upon a sexual revery. That firm arm reaching into pliant cavelike drapery is the very opposite of a modest gesture. This woman's self-absorption extends beyond the turned back and closed eyes.

There are no attributes to legitimate our calling this woman Venus: no roses, no myrtle, not even any silky pillow with gold threads embroidered into it. 9 There is no Cupid here; there is not even any cupiditas - no incitement to adore or to desire. Whereas Giorgione's Venus is a secular altarpiece, an image for adoration, this woman does not lie in state. In L'Arcadia, Sannazaro does describe a Venus seen from behind, "volta di spalle."'o But that Venus, who occurs in a pictorial representation rather than actually inhabiting Arcady, stands on exhibition at the Judgment of Paris. The pose of this Venus is remarkable because it constitutes artistic genius so to express inexpressible beauty; the invention is thus "non men sottile a pensare, che dilettevole a vedere." The visual paradigm for this tour de force was Timanthes' painting of Agamemnon's grief at the sacrifice of his daughter Iphigenia, as recorded by Pliny.

Nothing in Giulio's composition is so classical, so allied with myth or with formal, rhetorical conventions. There is no specific reference to antiquity, no regalia of loyalty to the ancient past. In this, Giulio's Reclining Woman is comparable to such works as Michelangelo's Battle of Centaurs, in which one peers and peers trying to see what is mythological about those figures. " ${ }^{\text {I }}$ Leonardo prefers emblems and dream images to myths, as being truer. Why does

\footnotetext{
${ }^{9}$ She is taken to be Venus by, among others, Rosand, 76; and Oberhuber, 31 3-20.

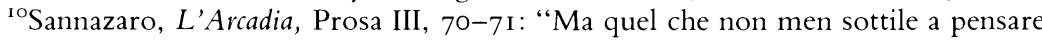
che dilettevole a vedere, era lo accorgimento del discreto pintore, il quale avendo fatta Giunone e Minerva di tanto extreme bellezza, che ad avanzarle sarebbe stato impossibile, e diffidandosi di fare Venere sì bella, come bisognava, la dipinse volta di spalle, scusando il difetto con la astuzia." For a study of how "pastoral and history mutually criticize each other" in Sannazaro's Arcadia, see Quint, 48-69.

"See on the relief, Lisner, 299-344.
} 
the eye see a surer thing in dreams than with the waking imagination, he asked. ${ }^{12}$ Likewise, Giulio denies the accoutrements of ancient myth and appropriates the purely pictorial significance of the mythical tradition while refusing the restrictions of that inheritance. The boldness of such a move is matched by its simplicity. ${ }^{\mathrm{r}}$

The most natural nude in Arcady is the standard nymph soon to be stumbled upon by a prowling satyr, and it is by no means immediately clear that this is not an option for the interpretation of Giulio's Woman. Still, she is not the usual sort of nymph. She is alone, and nymphs normally are either spied upon by satyrs or keeping company with other nymphs. The self-absorption of Giulio's seemingly undisturbable figure demands explication and gives the engraving a calm unexpected were the subject indeed an ordinary nymph. Giulio's figure is neither so regal as a Venus nor so accessible as the ordinary nymph.

How the engraving is interpreted depends on how much emphasis is given to the various deviations from pastoral norms, many of which deviations are merely omissions. Still, pastoral is a convention not tolerant of much tampering, and the more we attempt to fit Giulio's engraving into the types of pastoral imagery, the more pronounced its peculiarities become. It conforms in little more than the rejection of lofty decorum. Otherwise, it is plausibly the work of an artist playing with the possibility of erasing myth and its aura from art. Whereas pastoral puts meaning into landscape, here there is minimal landscape, and what little there is has been adulterated by buildings. Pastoral is about "piacevole ozio" and the longing for repose; this woman is the picture of discomfort as she props herself against that unpropitious stump. Pastoral is about innocence; this image is not. Pastoral is nostalgic, bearing the pretense to have been true once upon a time. Nothing in this image demands that we think back to primitive antiquity. Admittedly, pastoral is resistant

${ }^{12}$ J. P. Richter, II, 287, n. I 444: "Perchè vede piu certa la cosa l'ochio ne' sogni che colla imaginatione, stando desto?" Cf. a story that Lorenzo de' Medici, when accused of getting up late, replied "è val più quello che io sognava a cotest'hora, che ciò che voi facevate," in Wesselski, 38, n. 79. The anecdote is told also in Baldassare Castiglione's Il Libro del Cortegiano, bk. 2, lxx. Cardanus, 500, compares dreams and pictures as means of surpassing the limitations of nature: " $\&$ in somniis \& picturis quae maiora sunt quam quae naturae praestare possit." He assigns the cause to excessive coldness and/or humidity.

${ }^{13}$ See, on similar questions, Holberton, $3 \mathrm{I}-58$, esp. 58 on Jacopo de' Barbari’s Captives. 
to formulaic analyses. Its very essence, it has been said, is the invalidation of rational and linear, or even of precise, thought. ${ }^{14}$ Pastoral also is about a profound sense of time that, while not the timelessness of an icon, isn't the ticking clock of narrative, either. Perhaps the largest significance of pastoral in the Renaissance is that doubleness or masking of self so that fact and fiction are reconciled and truth becomes malleable, though at the same time elusive. Pastoral, in short, idealizes mystery rather than knowledge, even as its visualization relies on shadows rather than clarity of contours. Giulio's composition does not idealize; furthermore, there is sufficient deviation from basic elements of pastoral to suggest parody. This self-absorbed nymph-eyes closed and turning her back to the viewer-mocks the spiritualization of carnal love as well as disdaining the burlesque comedy of nymph and satyr scenes. Other engravings from roughly this time that show solitary figures from behind are characterizations of cheek or something very like it. ${ }^{\text {s }}$

Although the content of pastoral is vague and moody, the visual conventions of pastoral are quite predictable and not altogether elastic. The role of the female nude usually is either comic or iconic, and this figure's sleeping posture deviates insofar as it is not about vulnerability or implicit invitation. She is not to be identified as $\mathrm{Ve}-$ nus because to do so would be to ignore the rebuff the figure offers the male viewer. She lies there as a talisman by which men may view women without desire.

To make this woman not Venus and not an ordinary nymph allowed Giulio to avoid either simple seriousness or simple comedy. ${ }^{\text {It }}$ If the way the woman's head settles uncomfortably against a stump removes this image from others of luxurious languor, the delicacy of the sliding shadows Giulio so labored to create dignifies the composition without idealizing the figure. Without shadow there is no pastoral; and shadow, even more than the nude, is a fact of nature which was thoroughly poeticized for a Renaissance viewer. Shadow in Petrarchan poetry symbolizes escape from the

\footnotetext{
${ }^{14}$ See Snell, 28I-309; Sargeaunt, I64-86; Heninger, 254-6I; von Einem, 27-5I; Schmidt, 36-57; Maisak, esp. 87-99.

${ }^{15}$ Cf. Lucantonio degli Uberti's Salome (H. D.III.2) and Master PP's David with Goliath's Head (H. 5).

${ }^{16}$ This is not meant to exclude the possibility that the female body, shown here in its netherly aspect, metaphorically as well as literally, may have been amusing. On the back view as sometimes the "butt" of jokes, sec Frantz, 2 I.
} 
fiery rays of love. Here shadow helps to convey the idea of release from the rays of passion and also the metaphorical heavy darkness of corporeality and sleep. The twist is that rather than the woman portrayed in the shady woods escaping from fiery passion, the male viewer may. One of the lessons drawn from Venetian documentation of sex crimes by Guido Ruggiero is that passionate love, feared as a debilitating though temporary disorientation, was commonly distinguished from its favorable counterpart, moderate affection. ${ }^{17}$ The city that brought us the memorable spinoff on Apuleius' Golden Ass, that is, the Hypnerotomachia Poliphili, is a city that might well feel as great a need for visual tonics against the power of the female form as for the luscious oil paintings of Venus that Charles Hope has described as bedroom paraphernalia. ${ }^{18}$ Venice, a city with a highly developed courtesan culture, was also a place unusually well provided with treatises written by men for men on how to gaard against the weaker sex. ${ }^{19}$

Pietro Bembo wrote in Gli Asolani in I 505 about how men in ancient times used to pretend to think of women as nymphs and women's ensnaring of men - through their intense gaze, it is important to note-as the underlying truth in the metaphor of the hunt of woodland nymphs. ${ }^{20}$ Bembo chose to think of pastoral conventions as a convenient fiction whereby men might see in playful light the everyday reality of themselves as prey bound to be caught. Giulio's sleeping nymph begins to look like a twist in this game: the huntress is at rest, her dangerous eyes unthreatening. She is like a sleeping Cupid, though perhaps her image is less a tribute to love than a trace of real anxiety. There is a not inconsiderable literature of resentment against "la donna crudele" in sixteenth-century Italy. ${ }^{21}$ This literature and the legal cases in which women's enthrallment of men is prosecuted as criminal are as appropriate a context

\footnotetext{
${ }^{17}$ Ruggiero, 33, 66.

${ }^{18}$ Hope, I I I-24. On the social context, see Chojnacki, I26-48, and Olivieri, 95IO2.

${ }^{19}$ See Herlihy, 7 I-74. For the landmark De re uxoria (1416) of Francesco Barbaro, see Kohl and Witt, I $89-228$.

20"Finsero gli antichi uomini, che delle cacciatrici Ninfe favoleggiarono assai spesso e delle loro boscareccie prede, pigliando per le vaghe Ninfe le vaghe donne, che con le punte de' loro penetrevoli sguardi predono gli animi di qualunque uomo più fiero" (bk. 2, viii).

${ }^{21}$ One such impassioned lament may be found in Bembo's Gli Asolani, bk. I, xxxv: "E ora ecco di me, o Amore, che giuochi tu fai?" etc. Ariosto too inveighs against
} 
for viewing this engraving as is the visual tradition established by Giorgione. Giulio's engraving takes poetic convention and reconciles it with truth to things less ideal and more familiar. As Bembo in Gli Asolani acknowledged that poets and lovers use their license with truth almost to excess, ${ }^{22}$ so too might Giulio challenge the hardening of pictorial license into artificial convention.

So Giulio takes pastoral elements and brings them smack up against the language of the streets, for the one iconographic clue, the one latch to make sure interpretation does not go astray, is the tree stump. To call a man "un albero tagliato" was, Edward Muir has kindly informed me, tantamount to calling him a castrato. ${ }^{23}$ In this conspicuous stump, we find unambiguously presented a link between the recumbent female body and threat to the male. ${ }^{24}$

Let us return to the question of whether we are looking at a debased Giorgione, for if this engraving is a reproductive copy after Giorgione, it must be interpreted in accordance with what we

\footnotetext{
"Ingiustissimo Amor"; see recently Ascoli, 3 19-20. See also an engraving called The Allegory of Love, produced by a member of the school of Marcantonio Raimondi (B. $\mathrm{XV}, \mathrm{I}$ I) and including verses railing against love; discussed in Emison, I986, 42-44, n. I6. In this case, not only is love decried, but also the narrator's mother, "quella cruda del bel gioco acensa."

${ }^{22}$ Bk. 2, viii, "queste sono spezialissime licenze, non meno degli amanti che de' poeti, fingere le cose molte volte troppo da ogni forma di verità lontane."

${ }^{23}$ On the broader subject of street language and insult, see Edward Muir, The Mad Blood Stirring: Vendetta and Factions in Friuli During the Renaissance, forthcoming.

${ }^{24}$ It is an item Giulio's Reclining Woman shares with the Dresden Venus and with Titian's Three Ages of Man in Edinburgh, where the trunk appears in combination with the infant and senile stages. Certainly the presence of the trunk in the Dresden Venus complicates the problem of interpreting that painting. Like the buildings in the background, this motif too need not bear the same meaning as in Giulio's engraving despite the similarities. Given the pervading tranquility of the whole, it is not wholly arbitrary to take the trunk in the painting, less tall and exposed, as playing an important formal and symbolic role, a phallic reference without implications of castration. In Giulio's engraving, the trunk conveys the idea of discomfort, in conjunction with a nude whose attitude and arm positions suggest none of the same luxurious lassitude and convenient display of breast, etc. Again, though the buildings in both images deviate from strict pastoral expectations, those in the engraving are less homogeneous with the landscape. Rather than serving to shift the forms of landscape into a mode yet more horizontal, stable, and suggestive of shelter, they are spiky. Ciiorgione's buildings (or, as has been supposed since the time of Michiel, actually Titian's) suggest volumetric interior spaces; Giulio's, like the stump, are erect and fragile protrusions. Giulio, typically, comments rather than copying.
} 
know about that artist. ${ }^{25}$ To the extent that we are dealing with Giulio's independent invention, we have a different, more complicated, and less well-studied body of work as our control. Stylistically the work is reminiscent of Giorgione's atmospheric, quiet, and shadowy paintings. Even a detail such as the wrap of drapery over the woman's head reminds the viewer of Giorgione. Yet from what art historians have written, it would seem that there is no significant difference between Giulio's Reclining Woman and Giorgione's Dresden Venus, with the possible exception of as many as ten years disparity in date. ${ }^{26}$ That is, perhaps rashly, to turn similarity into near-identity. ${ }^{27}$ Yet how to explain Michiel's assertion that the miniature in the Paduan house of Pietro Bembo was "tratta da Zorzi"? Oberhuber asserts that the closest surviving figure by Giorgione is the nursing mother of the Tempest, a comparison that is less than striking and not intended to rule out the possibility of a lost Giorgione. ${ }^{28}$ If instead we turn Giulio's figure ninety degrees and reverse it, we find a form remarkably like that of the seated nude in the Concert Champetre. Though this comparison solves the riddle neatly only for those willing to entertain the possibility that Giorgione is the artist who conceived the Concert Champêtre, that is an attribution which has recently received renewed support on a variety of grounds, stylistic and technical. ${ }^{29}$ The match is one to be taken seriously. ${ }^{\circ}$ If the Giorgione from which Giulio's Reclining Woman derives is the Concert Champêtre, then the engraving is no more servilely about its formal sources than the Concert Champêtre

\footnotetext{
${ }^{25}$ See Wickhoff, 34ff; Hartlaub, 76ff; Calvesi, I 85 ; Hornig, 26. The notion of a lost Giorgione has been challenged by David Landau, in Hope and Martineau, 3 I 5 , P 13 and 3 I 8, Pis.

${ }^{26} \mathrm{On}$ the basis of Jaynie Anderson's proposed link between the painting and the marriage of Girolamo Marcello, ca. I 507 is the favored dating. The highly developed stippling effect in Giulio's engraving suggests a date considerably later than his dated print of I 509 , The Astrologer.

${ }^{27}$ Giulio's deathdate is unknown. He is last documented in I 5 is 5 .

${ }^{28}$ Oberhuber, 3 $13-20$.

${ }^{29}$ Hornig, 73-82; Krumrine, 5-9. The issue is not whether Titian or Giorgione singlehandedly painted the Concert Champêtre, but whether Bembo might have told Michiel that a figure based on the Concert Champêtre nude was based on Giorgione's design. The attribution claim is sufficiently weak that it can neither be bolstered nor much damaged by the evidence of connoisseurship.

${ }^{30} \mathrm{An}$ engraving from the circle of Giulio Campagnola, St. John Chrysostom (Hind I6), uses this same figure for the desired princess; see Kristeller, 22, n. I9. In this case the connection to the figure in the Concert Champêtre is even more readily recognized, for she too is seated.
} 
is, in turn, "reproductive of" the antique relief in the Grimani collection from which that same figure apparently derives. ${ }^{31}$

Though he was a master at creating subtleties of nondramatic visual meaning, formally Giulio was never highly inventive. It comes as no surprise, then, that the Reclining Woman is based on the righthand nymph in the Concert Champêtre, or according to a recent rereading by Francis Broun, the Earthly Venus. ${ }^{32}$ From the point of view of the two men in the painting, the city lad and the country lad, the nymph or Venus at the spring in certain ways resembles Giulio's figure as much as the seated one, for it is the more distant figure that they see from the back.

I have as yet scarcely mentioned the usual starting point for the discussion of Giulio's engraving, namely, Marcantonio's Dream ${ }^{33}$ (fig. 3). The resemblance between Marcantonio's foremost nude and Giulio's figure suggests that either one engraving is a source for the other or that both have a mutual source, that is, the supposed lost painting by Giorgione.

Giorgione was said by Michiel to have painted a scene of the inferno with Aeneas and Anchises. 34 There are two figures far in the background of Marcantonio's Dream whose poses may reflect a group of Aeneas and Anchises, though as they might have appeared at Troy rather than in Hades. There is, then, no good reason to suppose that we see here Giorgione's lost painting of Hades. Though what lost paintings by Giorgione may have looked like is anyone's guess, we should hesitate before assigning him something seemingly so uncharacteristic as a complex figural composition with dramatic architectural perspective, turbulence, and bold streams of light rather than spots of shimmer and refulgence. Even a detail like the long, loose hair of the women belies Giorgione's authorship. As sensuous a painter as Giorgione is, he doesn't do it with hair. Moreover, the Climber on the far right is apparently a motif taken from Michelangelo's Battle of Cascina in Florence (fig. 4), as Petrucci observed long since. ${ }^{35}$ Marcantonio studied this work-in-progress while sojourning in Florence on his way to Rome, circa I508;

${ }^{31} \mathrm{G}$. Richter, 234. See also Bober and Rubinstein, I 25, n. 93.

${ }^{32}$ Broun, 29-38. For an interpretation without Venuses, see Emison, I99 I, I95-96.

${ }^{33} \mathrm{On}$ this engraving, see Faietti and Oberhuber, i 56-58, n. 33; Shoemaker, 74, n. I2; and Landau in Hope and Martineau, 3 I 8, Pis. See also Gandolfo, 77-I I 2.

${ }^{34}$ In the house of Taddeo Contarini. Michiel, 88; Pignatti, I66.

${ }^{35}$ Petrucci, $392-406$. 


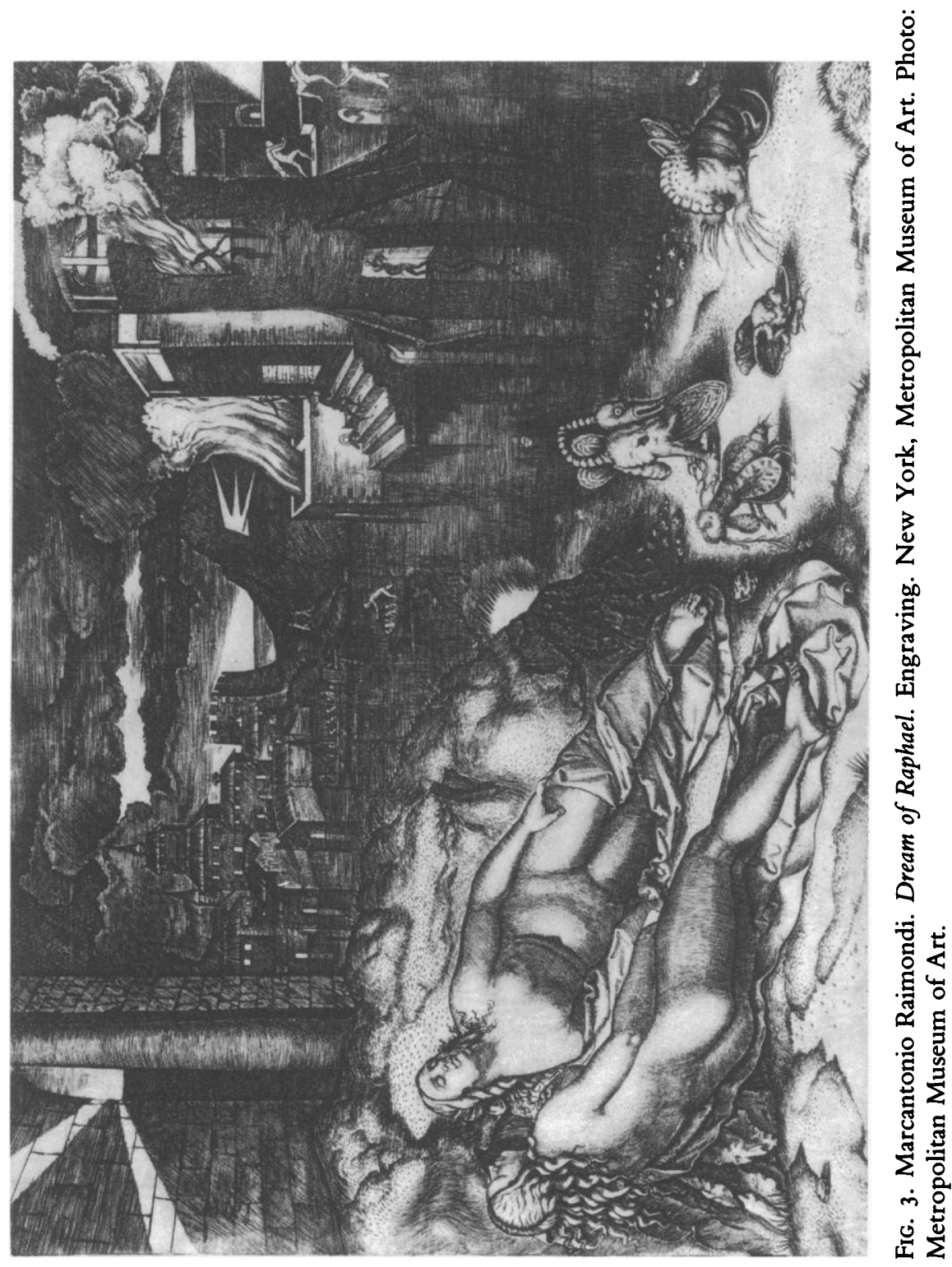




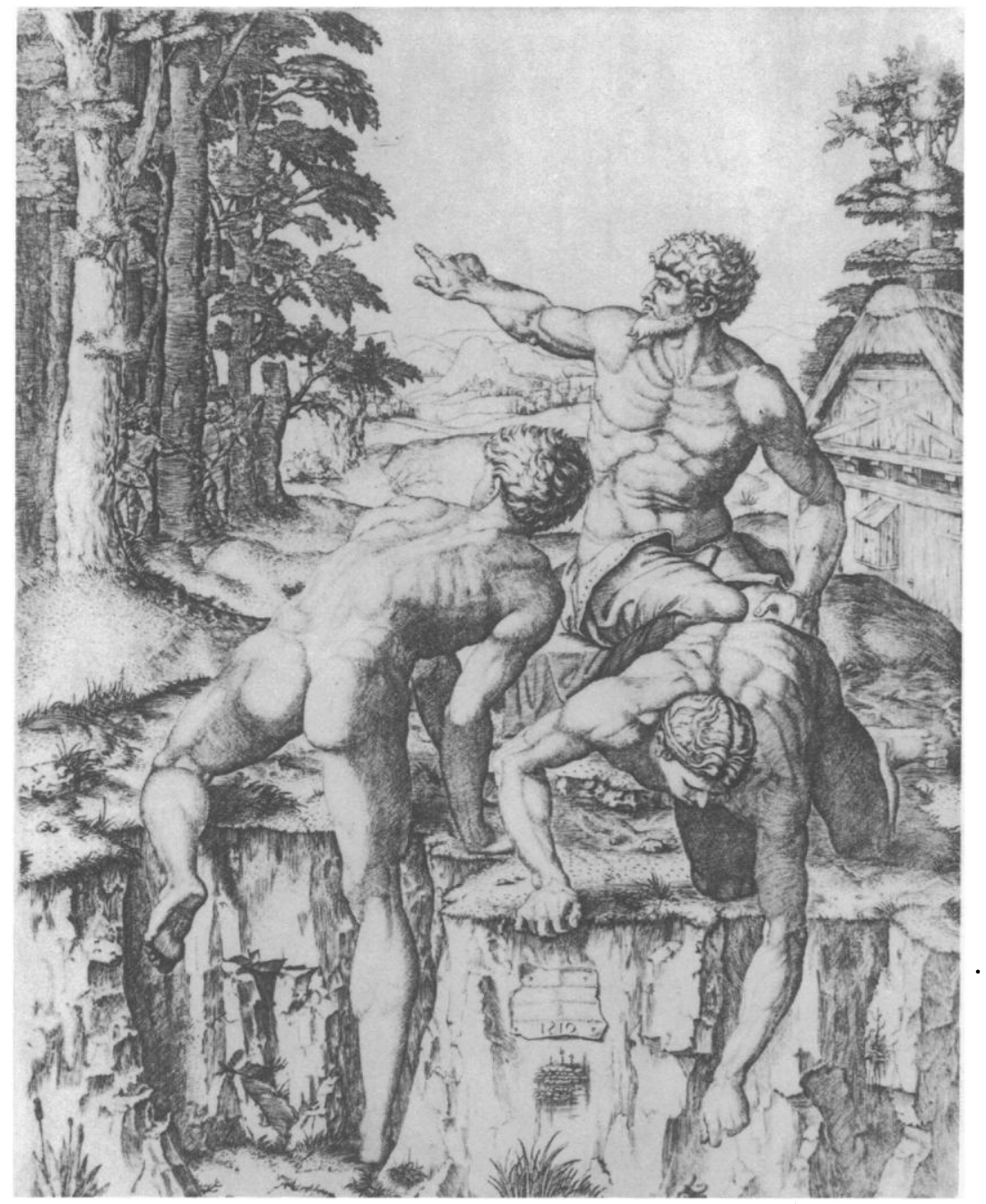

Fig. 4. Marcantonio Raimondi. The Climbers. Engraving. Budapest, Museum of Fine Arts. Photo: Museum of Fine Arts, Budapest. 
presumably Giorgione never saw it. ${ }^{36}$ The little monsters, commonly compared with Bosch because his paintings were collected in Venice by the time Michiel was writing and possibly this early too, are not strikingly like the types Bosch favors. ${ }^{37}$ Bosch's monsters tend to be humanoid and lithe; these are animated body parts. ${ }^{38}$ In all probability Marcantonio's engraving is not so Venetian an invention as has been claimed.

Clearly Marcantonio's engraving is a forbidding scene. As if a disjunct phallus weren't bad enough, the same creature is a winged ant, and Artemidorus in his handbook on the interpretation of dreams tells us that winged ants are evil omens. Crawling around the body, they herald death, for they are cold, black children of the earth. 39 The wheel of torture in the background, if this may be identified as Ixion's, suggests that the theme is rampant lust, a supposition reinforced by the combination of water and fire, for male heat

${ }^{36}$ Marcantonio, like Giorgione, might have learned about the cartoon without traveling to Florence, or by traveling there at a time unbeknownst to us, but the likelihood is as described above. Still the relationship to Michelangelo's design is useful evidence only in combination with other reasons to doubt the Venetian origin of the composition.

${ }^{37}$ As acknowledged by Holländer, I 80-8I. Roskill, 49-50, distinguishes between Marcantonio's dreams as ones of condensation and Bosch's as ones of displacement. See also de Tervarent, I 90-94; Slatkes, $335 \mathrm{ff}$. The creatures in Dosso's Dream are more like those of Bosch; see Gibbons, 222-23, n. 92. The possibility that this painting represents the Dream of Hecuba has no particular bearing on Marcantonio's Dream.

${ }^{38}$ Faietti and Oberhuber, I $56-58$, suggest a possible literary connection to Lucian's monsters on the Isola dei Sogni in the Verae historiae, as well as to Statius' descriptions of dreams for the flames and water. The reference to Lucian $(2.33-35)$, not as a text illustrated but as a visual source of a kind, is plausible. It might follow that the two women represent Truth (the woman in the Pudica/Veritas pose) and Falsehood as attributes of dreams. Although the Styx is normally a place of fire and water, that mythology has a natural resonance with the image of Night as the fiery sun sinking into the sea and the quasi-universal association of sleep as the image of death.

${ }^{39}$ Artemidoro di Daldi, 3.6, "Delle formiche": "Vedere formiche alate, non è buono, perchè predicono ruine $\&$ pellegrinaggio periglioso. Le altre chiamate operatrici a contadini giovano. . . . Ma se anderanno d'attorno il corpo, morte predicono, periochè sono figliuole della terra, \& fredda e nere." Artemidorus' work was published in Venice in I 5 I 8. See Winkler, 23-44. Another ancient writer on the subject of dreams, very popular and in print in Venice from I 47 I, was Valerius Maximus. He associates shadow and dream in what one might describe as chaos theory avant la lettre, the gist being that we must accommodate ourselves to what is true rather than expect to understand the reasons with perspicuity. 
and female humidity were the very stuff of the works of Venus. ${ }^{40}$ The subject, then, is the "infernal" parts. Sexuality is monstrous and hell is the inviting female chasm (a metaphor that goes back at least to Boccaccio). The pairing of female nudes might suggest further negative connotations. When the French sixteenth-century author Brantôme mentioned female homosexuality, he associated it with Italy, calling it "donna con donna." 41 Giulio's engraving depends upon an idea of independent female sexuality but treats women less judgmentally than Marcantonio's, eliminating the damnation of the male as well as the literal duplicity of the female. ${ }^{42}$

Very likely Giulio used both Marcantonio's engraving and the Concert Champetre as formal sources. The figures in the two supposedly reproductive engravings are not similar enough in details to substantiate any mutual loyalty to a lost original. Marcantonio's figure lies in a more extended position and is differently lit. The Venus Pudica pose suggests a source in statuary, a standing figure placed sideways. The shadows are modelled for sculptural effect rather than in delicate gradations suggesting tactility. Giulio's figure, not explicitly a Venus Pudica, slumps as though tilted from a seated position, more bent than Marcantonio's comparable figure. Giulio's very definitely has a center of gravity in the mid-section. Her proportions are stumpier, and her right thigh is not balanced on top of the left. Nevertheless, the two engravings have both formal and thematic similarities. Marcantonio's Dream braids together themes of love and desire, sleep and death, the world of myth and the world of dreams. Giulio's engraving, having eliminated nearly all iconography, better adheres to the topos of the dream than to

${ }^{40}$ Tomeo Leonicus, 58, in the Quaestiones amatoriae: "Calido nempe \& humido, quiusmodi genitale est semen, ad Veneris operas indigemus maxime." On his art historical connection with Giulio's father, see Schlosser, 2 I6. On Giulio's interesting father, see Galichon, 332-46, and Safarik, 3 I 7-18. See also Filelfo's commentary on Petrarch, $5 \mathrm{v}$, in which heat and humidity are said to characterize men and women, respectively.

${ }^{4}$ 'Brantôme, I39. See further Federman, esp. 23-24; Flandrin, 27-48. For an uncensorious anecdote about female masturbation, see Wesselski, 24. Aretino not only uses the word nymph as a humorous synonym for woman but describes female masturbation and anal sex, either of which might be judged relevant to Giulio's presentation of the figure. On the quasi-conventional pairing of humanism and homosexuality, if only on the metaphorical and satirical level, see Ascoli, I I3-I6.

${ }^{42}$ The pairing of the women, here as in the Concert Champêtre, militates against taking the painting to be a narrative. Not having any obvious protagonist on which to focus, the viewer tries to put together the ensemble rather than narrative moments. 
the genre of pastoral. The two are not neatly distinct, however. Sannazaro dreams of a graveyard and an underworld populated with nymphs at the end of Arcadia; the subject of the Hypnerotomachia Poliphili is a dream similarly ominous with the theme of death. ${ }^{43}$ Apuleius' dream is steeped in fear of lustful women. When defined as "a true fiction of the soul," a dream is like pictorial imagination. And according to Artemidorus, a dream is a "fiction of the soul in a diverse form, signifying either good, or evil, to come. . . . As in all other things there is an order and dependence." If what we see here represents that surer imagination of dreams, we are licensed to take this woman as ominous in the etymological sense, as signifying, to use Artemidorus' words, either good or evil to come. Giulio's Reclining Woman is a true fiction of the soul, neither divine nor evil-like a dream. As there were conventions available for idealizing women, visual as well as verbal ones, so there were conventions available for looking upon women as problematic. Here visual ones were slower to develop than verbal ones. If we accept this reading of Giulio's engraving, seeing it now as significantly different from Giorgione's luscious reclining goddess, we need to wonder how many of these less idealizing conventions we still fail to recognize.

The women in the Concert Champêtre have sometimes been described by art historians as personifications of the beauty of landscape. ${ }^{44}$ Vague though such a claim is, it may be valid. In the case of the engraving, expressly because of the reduction of iconography, an identity between woman and earth may be taken to be part of the design. Giulio's Reclining Woman as an object of either desire or trepidation is like the land on which she spreads herself. 45 The act of reclining has become the principal iconography of the image.

\footnotetext{
${ }^{43} \mathrm{Kemp}, 347-98$, scarcely mentioned dreams. The exception is the Hypncrotomachia Poliphili.

${ }^{44} \mathrm{Fehl}$, I 53-68. It is worth remembering, in relation to Giulio's treatment of the nude, the lack of apparent erotic appeal to the men in this painting. Although it is a tricky thing to say whether Giulio's woman is heavier than the ideal woman would be, Equicola, I619, stated as a desideratum "non grassa, ma carnosa."

45Paul Kaplan, the chair of the session at which this paper was first delivered, suggested that the anxiety specifically associated with lainded holdings during the War of the League of Cambrai is more pertinent than desire in itself. See further on reflections of the war, Kaplan, 405-27, and on the war itself, Gilbert, 274-92. See also on terra mater, identified with either Pomona or Vesta, Kliemann, 300-o I, citing Giovanni Nanni's Antiquitatum variarum volumina of 15 I2, as well as, on a more popular level, St. Francis' Canticle of the Creatures.
} 
Ancient authors, Ovid for example, spoke without apology of women as fields to be ploughed, ${ }^{46}$ and Luigi Dardano, writing in Venice in I5IO, similarly described a woman as a natural thing given by God to be used with discretion, in herself no worse than the earth which is made good by good seed. 47 To interpret a woman as like the earth was to see her as in need of discipline and cultivation, though not in herself a power threatening evil. Needless-tosay, this is a drastically different philosophy of the female than the Neoplatonic or Petrarchan. ${ }^{48}$ It was, furthermore, a convenient one for a Venice intending to satisfy its ambitions increasingly upon the land rather than upon the sea. ${ }^{49}$ Indeed, one of Dardano's other metaphors for men's retrieval of good from so unlikely a thing as the female body is to describe the offspring as a pearl retrieved from an oyster. The metaphor of woman as cold, wet earth may not be sufficient to explain Giulio's intentions, but it is at some level necessary in order to understand the meanings of the image.

To make of this engraving no more than an offshoot of Giorgione's career, especially to subordinate it to a hypothetical lost painting of dubious status, is to make the Renaissance narrower

${ }^{46}$ In bk. I of the Ars Amatoria. See Myerowitz, I09, 127.

${ }^{47}$ Dardano, 54: "Ma al proposito della donna se l'usarai moderatamente, e a quel fine che l'hà creata Dio, non te la facendo Iddolo, e se secondo la convenevolezza la ciberai vestirai accarezzerai ti sarà obediente, e buona, e ottimo ne raccoglierai frutto tenendo sempre la briglia in mano, e dandole buoni essempii, ne vitiandola: come anco s'ha vesti una buona terra, e in quella feminasti zizania non raccoglieresti frumento, ne altra biada non per difetto della terra ch'è buona, ma per la semenza rea, et inutile. Anchora il vino è buono a chi moderatamente l'usa a chi fa'l contrario nuoce, e questo istesso di tutte l'arti aviene lequali per loro natura sono buone e senza peccato, ma chi quelle mal'usa le fa mendacemente incolpare, e l'errore di pravi artifici ascrive a l'arte. . . . Cosi è della donna la qual non sola è buona per se, ma ogni sua coniuntione è conımoda, e desiderabile come descrive Cicerone comune cosa in tutti li animanti e l'appetito della coniuntione cagione di generare, e certa cura de quelle cose, che son generate. Se dunque l'huomo usarà la donna a fine di procreare, e discacciar lo stimolo della carne sanamente intendendo ogni cosa di quella procederà in bene." 'See also on this treatise, Herlihy, 7I-74. Such a metaphor is not unique to Dardano; see also Palmieri, much earlier, bk. 3: "La moglie è in luogo della seconda terra, la quale il seme ricevuto, nutrica \& multiplica in abondante, \& buono frutto" (first published only in I 529).

${ }^{48}$ Miles, $193-208$, has argued that the social instability of the fourteenth century fostered defensive perceptions of women and that anxieties about both women and food shortages are traceable in the subliminal eroticism of the partially naked, nursing Virgin. She attempts societal diagnosis on the basis of an artistic type; I am dealing not with a type but with an exceptional image and mean to argue on behalf of my interpretation's plausibility by reference to social stereotypes.

${ }^{49}$ See Woolf, I8I-82, and Priuli, 7-8 (4 June I 509). 
than it was. Giulio chose not to present Venus in any mythological or literary sense, a task that would have brought with it a whole range of obligations. Neither did he portray the traditional nymph, a subject of lower status and correspondingly fewer obligations of decorum, but one which tended to veer too radically in the other direction, toward comedy. He gave up the claim to immediate significance the standard iconography of his time offered and gave up as well the reference to admired antiquity. We know that the mainstream of Renaissance art served conventional beliefs of a highly idealistic and philosophical bent or religious tenets. Yet even within the constraints of Renaissance style, more ordinary attitudes toward women than the idealizing ones could be pictured. When and how heterodoxy of various sorts, or even mild cynicism, entered visual imagery, whether consciously or not, is a history yet to be written. ${ }^{\text {so }}$

There is more to the history of the Venetian nude than literary and mythological examples on the one hand and realistic genre scenes on the other. Deliberately remote rather than merely serene, this woman lies, perhaps in revery and herself quite dreamlike. Neither divine nor evil, this nude challenges the viewer without having to gaze at him to do it. The engraving gives us occasion to reconsider the question: what was the breadth of Renaissance thinking, supposing, worrying, and conversational commonplaces that artists could make use of? Venus, as the goddess of love, as well as the patron goddess of ancient Rome, was often adaptable to Renaissance purposes, but so was, on this occasion at least, an ordinary female nude.

University of New Hampshire

${ }^{5 \circ}$ Craig Harbison, "Meaning in Venetian Renaissance Art: The Issue's of Artistic Ingenuity and Oral Tradition," Art History (1992): 19-37, only came to my attention after this article went to press. 


\section{Bibliography}

Anderson, Jaynie. "Giorgione, Titian and the Sleeping Venus." In Tiziano e Venezia, Convegno Internazionale di Studi, 33742. Vicenza, 1980.

Aretino, Pietro. The Ragionamenti. Ed. Peter Strafford. London, 1970.

Artenidoro di Daldi. Dell'interpretatione de' sogni [ I 542]. Milan, 1976.

Ascoli. Albert. Arisoto's Bitter Harmony, Crisis and Evasion in the Italian Renaissance. Princeton, NJ, 1987.

Bober, Phyllis P., and Ruth O. Rubinstein. Renaissance Artists and Antique Sculpture. London, 1986.

Brantôme. Les plus verts discours des Dames Galantes. Ed. M. Bastide. Paris, 1966.

Broun, Francis. "The Louvre 'Concert Champêtre': A Neoplatonic Interpretation." In Ficino and Renaissance Neoplatonism, ed. Konrad Eisenbichler and Olga Ż. Pugliese, 29-38. Ottawa, 1986.

Calvesi, Maurizio. "La 'morte dibacio,' Saggio sull'eretismo di Giorgione." Storia dell'arte $7 / 8$ (1970): 185.

Cardanus, Hieronymus. De subtilitate. Basel, I 560 .

Chojnacki, Stanley. "The Power of Love: Wives and Husbands in Late Medieval Venice." In Women and Pou'er in the Middle Ages, ed. M. Erler and M. Kowaleski, I 26-48. Athens, GA, I988.

Cook, Albert. Dimensions of the Sign in Art. Hanover, NH, 1989.

Dardano, Luigi. La bella e dotta difesa delle donne in versa, c prosa. Venice, I 554.

Eiche, Sabine. "On the Dispersal of Cardinal Bembo's Collections." Mitteilungen des Kunsthistorischen Institutes in Florenz 27 (1983): 353-59.

Einen, Herbert von. Giorgione, der Maler als Dichter. Akadenie der Wissenschaften und der Literatur. Mainz, 1972.

Enison, Patricia. The Art of Teaching: Sixtecnth-Century Allegorical Prints and Draunings. Exh. cat., Yale University Art
Gallery. New Haven, 1986.

__ "The Concert Champêtre and Gilding the Lily." Burlington Magazine I 33 (I99I): 195-96.

Equicola, Mario. Libro di natura d'amore [ I 526]. In Scritti d'arte del Cinquecento, vol. II, ed. Paola Barocchi. Milan, I973.

Faictti, Marzia, and Konrad Oberhuber. Bologna e l'umanesimo, 1490-1510. Exh. cat., I'inacoteca Nazionale. Bologna, 1988.

Federman, Lillian. Surpassing the Love of Men: Romantic Friendship and Love Betu'een Women from the Renaissance to the Present. New York, I98I.

Fehl, Philip. "The Hidden Genre: A Study of the Concert Champetre in the Louvre." Journal of Aesthetics and Art Criticism 16 (1957): I 53-68.

Filelfo, Francesco. See Petrarch.

Flandrin, Jean Louis. "Repression and Change in the Sexual Life of Young People in Medieval and Early Modern Times." In Family and Sexuality in French History, ed. Robert Wheaton and Tamara Hareven, 27-48. Philadelphia, I980.

Frantz, David. "Festum Voluptatis," A Study of Renaissance Erotica. Columbus, $\mathrm{OH}$, 1989.

Freedberg, David. The Power of Images: Studi's in the History and Theory of Response. ('hicago, 1989.

Freedberg, S. J. Painting in Italy, 1500 to 1600. Harmondsworth, 1975.

Frimmel, T., ed. Marcantonio Michiel's Notizia d'Opere del.Disegno. Quellenschriften fiir Kinnstgeschichte. Berlin, I 888.

Galichon, Émile. "Giulio Campagnola, Peintre-Graveur du XVIe siècle." Gazette des Beaux-Arts I 3 (I862): 332-46.

Gandolfo, F. "Il Dolce Tempo." Mistica, Ermetismo e Sogno nel Cinquecento. Rome, 1978.

Gibbons, Felton. Dosso and Battista Dossi, Court Painters at Ferrara. Princeton, NJ, 1968. 
Gilbert, Felix. "Venice in the Crisis of Cambrai." In Renaissance Venice, ed. J. R. Hale, 274-92. London, 1973.

Ginzburg, Carlo. "Tiziano, Ovidio e i codici della figurazione erotica nel 'soo." In Tiziano e Venezia, Convegno Internazionale di Studi, I25-35. Vicenza, I980.

Goffen, Rona. "Renaissance Dreams." Renaissance Quarterly 40 (I987): 682-706.

Goldner, George. "A Source for Titian's Nymph and Shepherd." Burlington Magazine I I6 (1974): 392-95.

Hartlaub, G. "Giorgione im graphischen Nachbild." Pantheon I 8 (1960): 76-84.

Heninger, S. K. "The Renaissance Perversion of Pastoral." Journal of the History of Ideas 20 ( I 96 I): 254-6 I

Herlihy, David. "Populazione e strutture sociali dal XV al XVI secolo." In Tiziano e Venezia, Convegno internazionale di studi, 7I-74. Vicenza, I980.

Hind, A. M. Early Italian Engraving. London, 1948 .

Holberton, Paul. "Of Antique and Other Figures: Metaphors in Early Renaissance Art." Word and Image I (1985): 3 I- 58 .

Holländer, H. Hicronymus Bosch, Weltbilder und Traumuerk. Cologne, 1975.

Hope, Charles. "Problems of Interpretation in Titian's Erotic Paintings." In Tiziano c Venezia, Convegno internazionale di studi, I I I-24. Vicenza, I 980.

- and Jane Martineau, eds. The Genius of Venice, 1500-1600. Exh. cat., Royal Academy of Art. London, 1983.

Hornig, Christian. Giorgiones Spätuerk. Munich, 1987.

Kaplan, Paul. "The Storm of War: The Paduan Key to Giorgione's Tempesta." Art History 9 (1986): 405-27.

Katalog der ausgestellten Gemälde des 13.-18. Jahrhunderts. Gemäldegalerie, Staatliche Museen Preussischer Kulturbesitz. Berlin, 1975.

Kemp, Martin. "From 'Mimesis' to 'Fantasia." "Viator 8 (I977): 347-98.

Kliemann, Julian. "Vertumnus und Pomona: Zum Programm von Pontornoo's Fresko in Poggio a Caiano." Mitteilungen des Kunsthistorischen Institutes in Florenz I6 (I 972): 300-OI.

Kohl, Benjamin, and Ronald Witt. The
Earthly Republic: Italian, Humanists on Government and Society. Philadelphia, I 978 .

Kristeller, Paul. Giulio Campagnola. Berlin, I907.

Krumrine, Mary. "Alcune osservazioni sulle radiografie del Concerto Campestre." Antichità viva 20/3 (198I): 5-9.

Lisner, Margit. "Form und Sinngehalt von Michelangelos Kentaurenschlacht mit Notizien zu Bertoldo di Giovanni." Mitteilungen des Kunsthistorischen Institutes in Florenz 24 (1980): 299-344.

Maisak, Petra. Arkadien, Genese und Typologie eincr idyllischen Wunschuelt. Bern, I98 I.

Mayor, A. H. "Giulio Campagnola." Bulletin of the Metropolitan Museum of Art 32 (1937): 192-96.

Meier, Henry. "Giulio Campagnola's 'Wonnan Reclining in a Landscape' and Its Technique." Bulletin of the New" York Public Library 46 (1942): 735-38.

Meiss, Millard. The Painter's Choice. New York, 1976.

Miles, Margaret. "The Virgin's One Bare Breast: Female Nudity and Religious Meaning in Tuscan Early Renaissance Culture." In The Female Body in Western Culture: Contemporary Perspectives, ed. Susan Suleinan, 193-208. Cambridge, MA, 1986.

Myerowitz, Molly. Ovid's Games of Love. Detroit, I985.

Oberhuber, Konrad. "Giorgione and the Graphic Arts of His Time." In Giorgione: Atti del convegno internazionale di studio per il $5^{\circ}$ centenario della nascita, 3 I3-20. Castelfranco Veneto, I979.

- , and Marzia Faietti. See Faietti.

Olivieri, Achille. "Eroticism and Social Groups in Sixteenth-Century Venice: The Courtesan." In Western Sexuality: Practice and Precept in Past and Present Times, ed. Philippe Ariès and André Béjin, tr., A. Forster, 95-102. Oxford, Eng., I985.

Palmieri, Matteo. Libro della vita civile. Florence, 1529.

Petrarch, Francesco. Li sonetti. Ed. Francesco Filelfo. Venice, I 5 I9.

Petrucci, A. "Disegni e stampe di Marcanto 
nio." Bolletino d'arte, 3 d ser., 30 (I937): 392-406.

Pignatti, Teresio. Giorgione. London, I97I.

Priuli, Girolamo. I Diarii [1499-I5I2]. In Rerum Italicarum Scriptores, 24, pt. 3, 4, ed. Roberto Cessi. Bologna, I912-28.

Quint, David. Origin and Originality in Renaissance Literature: Versions of the Source. New Haven, 1983.

Richter, Georg. Giorgio da Castelfranco. Chicago, 1937.

Richter, Jean Paul, ed., The Notebooks of Leonardo da Vinci, New York, 1970.

Rosand, David. "Giorgione, Venice, and the Pastoral Vision." In Places of Delight: The Pastoral Landscape. Exh. cat., The Phillips Collection, 20-8I. Washington, D.C., I988.

Roskill, Mark. The Interpretation of Pictures. Amherst, 1989.

Ruggiero, Guido. The Boundaries of Eros: Sex, Crime and Sexuality in Renaissance Venice. Oxford, Eng., I985.

Russell, H. Diane. Eva/Ave: Woman in Renaissance and Baroque Prints. Exh. cat., $\mathrm{Na}$ tional Gallery of Art. Washington, D.C., I990.

Safarik, E. "Giulio Campagnola." In Dizi onario bibliografico degli italiani, I 7: 3 1 7- 18 . Rome, 1974.

Sannazaro, Jacopo. Opere. E. Carrara, ed. Turin, 1952.

Sargeaunt, G. M. Classical Studies. London, I929.

Saxl, Fritz. Lectures. London, 1957.

Schlosser, Julius. La letteratura artistica. F. Rossi, tr. Florence, 1977.
Schmidt, E. "Arkadien: Abendland und Antike." Antike und Abendland 2 I (1975): 3657.

Shoemaker, Innis. The Engravings of Marcantonio Raimondi. Exh. cat., Spencer Museum of Art. Lawrence, KS, I98I.

Slatkes, L. "Hieronymous Bosch and Italy." Art Bulletin 57 (1975): 335-45.

Snell, Bruno. "Arcadia: The Discovery of a Spiritual Landscape." In The Discovery of the Mind, The Greek Origins of European Thought, tr. T. G. Rosenmeyer, 28 I-309. New York, I960.

Tervarent, Georges de. "Instances of Flen1ish Influence in Italian AA." Burlington Magazine 85 (1944): 190-94.

Tomeo Leonicus, Niccolò. Opuscula. Venice, 1525.

Wesselski, Albert. Angelo Polizianos Tagebuch. Jena, I 929.

Wickhoff, F. "Giorgiones Bilder zu römischen Heldengedichten." Jahrbuch der königlich preussischen Kunstsammlungen I 6 (1895): 34-43.

Winkler, John J. The Constraints of Desire: The Anthropology of Sex and Gender in Ancicht Grece, New York and London, I990.

Woolf, Stuart J. "Venice and the Terrafirma: Problems of the Change from Commercial to Landed Activities." In Crisis and Change in the Venetian Economy in the Sixtecnth and Seventeenth Centuries, ed. Brian Pullan, 175-203. London, 1968.

Zucker, Mark. The Illustrated Bartsch, Commentary, 35. New York, 1984. 